\title{
Pogodnost standardnog sortimenta jabuke u uvjetima ekološke proizvodnje
}

\section{Sažetak}

Posljednjih deset godina svjedoci smo klimatskih promjena uslijed djelovanja različitih štetnih utjecaja na okoliš. U poljoprivrednoj proizvodnji rješenja se sve više traže u ekološkoj proizvodnji koja se temelji na korištenju metoda koje ne ometaju prirodne zakone te ne djeluju štetno na agroekološki sustav kao ni na zdravlje ljudi. S obzirom na velike troškove sadnje novog sortimenta prilikom prelaska na ekološku proizvodnju, cilj ovog istraživanja je bio utvrditi osjetljivost standardnih sorti na glavnu bolest jabuke, mrljavost lista i krastavost ploda (Venturia inaequalis), u sustavu ekološke zaštite u usporedbi s kontrolom tj. ne tretiranim djelom pokusa. Drugi cilj je bio utvrditi učinkovitost ekološkog tretmana na otpornom ili tolerantnom sortimentu jabuke. Dvogodišnji rezultati istraživanja pokazali su da su sorte 'Elshof' $i$ 'Elstar' pokazale najmanju osjetljivost plodova na krastavost u ekološkom tretmanu ali i u usporedbi sa svim ostalim standardnim sortama $u$ istraživanju. Od tolerantnih sorti najvišu otpornost je pokazala sorta 'Enterprise'. Sorta 'Priam' se također pokazala kao pogodna sorta za ekološki uzgoj i zadržala je stabilnost priroda u obje istraživane godine.

Ključne riječi: ekološka zaštita, jabuka, sorta, krastavost, Venturia inaequalis

\section{Uvod}

Međunarodna organizacija za biološku i integriranu zaštitu (IOBC) definirala je integriranu voćarsku proizvodnju kao „ekonomičnu proizvodnju visokokvalitetnog voća, dajući prednost ekološki sigurnijim metodama, minimizirajući nepoželjne nuspojave i uporabu pesticida, kako bi se poboljšala zaštita okoliša i ljudsko zdravlje" (Anonymous, 2002). Smjernice integrirane proizvodnje su u skladu s GAP ('Good Agricultural Practice' - dobra poljoprivredna praksa) sustavom certifikacije koji je postavljen kao zahtjev mnogih europskih zemalja prilikom uvoza voća (Carroll i Robinson, 2004). Integrirana proizvodnja je veliki iskorak u odnosu na konvencionalnu proizvodnju. Ekološka ili organska proizvodnja je još jedan „korak“ dalje u odnosu na integriranu jer zabranjuje primjenu većine kemijskih pesticida i umjetnih mineralnih gnojiva. Dozvoljena je uporaba pesticida i gnojiva isključivo organskog porijekla, od kojih neki imaju funkciju biostimulatora koji izravno ili neizravno utječu na podizanje biljne kondicije. Ekološka proizvodnja je strogo regulirana i sva roba na tržište dolazi obilježena i sa certifikatom. Prema istraživanjima iz Mađarske i SAD-a plodovi iz ekološkog uzgoja imaju jaču aromu u odnosu na iste sorte iz integrirane proizvodnje (Gonda i sur., 2000, Andrews i sur. 2001). Većina standardnog sortimenta jabuke je neotporna na glavnu gljivičnu bolest te kulture, krastavost ploda (Venturia inaequalis) (Biggs, 1990; Chevalier i sur., 1991; Sandskär, 2003). Problemi vezani uz simptome bolesti na plodu postaju veći u ekološkoj proizvodnji jer ne postoje dovoljno učinkoviti preparati za prevenciju, naročito ako se radi o osjetljivim sortama. Sve više raste interes za tolerantnim sortama koje imaju visoke prirode, a plodovi su bez simptoma krastavosti i bez uporabe kemijskih pesticida (Janse, 1993; Kellerhals i sur.,1997; Sansavini i sur.,2004). Istraživanja u SAD-u su pokazala da je ekološka proizvodnja puno isplativija i održivija u sušnijim područjima, a plodovi imaju bolja organoleptička svojstva (Reganold i sur., 2001; Peck i sur, 2006).

dr.sc. Vesna Tomaš, dr.sc. Ines Mihaljević, DominikVuković, mag.ing.agr., dr.sc Marija Viljevac-Vuletić, dr.sc. Zvonimir Zdunić, Poljoprivredni institut 0sijek, Odjel za voćrstvo, Južno predgrađe 17,31000 0sijek, Hrvatska doc.dr.sc. Krunoslav Dugaliç, Hrvatska agencija za poljoprivredu i hranu, Ured ravnatelja, Vinkovačka cesta 63C, 31000 0sijek, Hrvatska Autor za korespondenciju:vesna.tomas@poljinos.hr 


\section{Materijal i metode}

Istraživanje je provedeno na Poljoprivrednom institutu Osijek na pokusnom nasadu Tovljač tijekom dvije godine (2011 - 2012). Ukupna površina pokusnog nasada iznosila je 0,3 ha. Uzgojni oblik je vretenasti grm. Godina sadnje nasada je 2005. U pokusu je bilo ukupno 29 sorata jabuke (15 standardnih i 14 tolerantnih sorti (Tablica 1) na glavnu bolest jabuke, mrljavost lista i krastavost ploda jabuke). Sve sorte su posađene u slučajnom blok rasporedu s po tri stabla standardne sorte $\mathrm{u}$ bloku i s po četiri stabla tolerantne sorte u bloku u četiri ponavljanja. U istraživanju je bilo dva tretmana (tretman 1. - ekološki i tretman 2. - kontrola tj. ne tretirani dio). Kontrola je bila prostorno izolirana od ekološkog tretmana u dva posebna reda sa po tri stabla u bloku od svake standardne sorte i sa četiri stabla od svake tolerantne sorte u četiri ponavljanja isto kao i u ekološkom tretmanu. Rezultati osjetljivosti s obzirom na pojavnost i jačinu simptoma bolesti na listu i plodu bili su određeni na temelju vizualnih pregleda i procjene zahvaćenosti simptomima površine lista (\%) ili ploda $\left(\mathrm{cm}^{2}\right)$ na osnovi 100 listova i 100 plodova po sorti i tretmanu. Listovi bez simptoma tj. zdravi listovi su ocjenjeni sa 0 . Listovi sa simptomima koji su zahvatili do $25 \%$ lisne površine ili manje su ocijenjeni sa 25 , dok su listovi sa simptomima koji su zahvatili više od $25 \%$ lisne površine su ocijenjeni sa 50 . Ocjena osjetljivosti ploda izvršena je po istom principu. Zdravi plodovi su ocijenjeni sa 0 . Ukoliko je površina ploda bila zahvaćena simptomima manje od $1 \mathrm{~cm}^{2}$ plod je ocijenjen je sa 25 , a ukoliko su simptomi krastavosti prelazili $1 \mathrm{~cm}^{2}$ plod je ocijenjen sa 50 . Ocjena lista i ploda koja je bila u najvećem broju zastupljena po sorti i tretmanu zabilježila se kao referentna.

Pokusni nasad se redovito tretirao s obzirom na prevenciju bolesti ovisno o vremenskim prilikama osim kontrolnih redova. Sve sorte u ekološkom tretmanu (tolerantne i standardne) su bile tretirane sa istim sredstvima koja su dozvoljena u ekološkoj zaštiti i u istim rokovima. Sredstva koja su korištena u pokusu bila su Cuprablau-Z (bakarni oksiklorid), Chromosul 80 (sumpor), Neemazal TS (koštice iz neem drveta), Cutisan (mljeveni kaolin), Mycosin Vin (sumporasto kisela glinica i biljni ekstrakati), Cocana (kalijev sapun), Granupom (CpGV), Vitisan (kalij hidrogenkarbonat) prema uputama za primjenu.

Tablica 1. Sorte jabuke u pokusu /

Table 1. Apple varieties in the experiment

\begin{tabular}{cll}
\hline Redni broj & Naziv sorte (standardne) & Naziv sorte (tolerantne) \\
\hline 1. & 'BELGOLDEN' & 'COOPER 7A' \\
\hline 2. & 'ELSHOF' & 'COOPER 7SB2' \\
\hline 3. & 'ELSTAR' & 'ENTERPRISE' \\
\hline 4. & 'FUJI BC 2' & 'GOLD CHIEF' \\
\hline 5. & 'GALA MITCHGLA' & 'LYBERTY' \\
\hline 6. & 'GALA MUST' & 'NOVA EASYGRO' \\
\hline 7. & 'GALA GALAXY' & 'PRIAM' \\
\hline 8. & 'PRINC GALAMUST' & 'REALKA' \\
\hline 9. & 'GOLDEN DELICIOUS B' & 'RENE' \\
\hline 10. & 'GRANNY SMITH' & 'REWENA' \\
\hline 11. & 'IDARED' & 'SIR PRIZE' \\
\hline 12. & 'JONAGOLD' & 'SPARTAN' \\
\hline 13. & 'JONAGORED' & 'TOPAZ' \\
\hline 14. & 'LYSGOLDEN' & \\
\hline 15. & 'TOPRED DELICIOUS' & \\
\hline
\end{tabular}


Meteorološki podaci su se prikupljali s meteorološke stanice CDA koja se nalazila u pokusnom voćnjaku. Praćeni parametri su temperatura zraka $\left({ }^{\circ} \mathrm{C}\right)$, količina oborina $\left(\mathrm{mm} / \mathrm{m}^{2}\right)$, relativna vlaga zraka (\%). Prikupljeni podaci su pokazali da je 2012. godina bila puno zahtjevnija godina u pogledu intenziteta pojave bolesti u odnosu na 2011. U periodu od travnja do listopada tijekom 2012. godine zabilježene su ukupno 32 infekcije s Venturia inaequalis, koje su bile uvjetovane dužinom vlaženja nekad i u trajanju od nekoliko dana bez prestanka (14.04.-19.04.; 13.05.-15.05.;22.05.-24.05.; 28.05-2.06.) te srednjom dnevnom temperaturom. Tijekom 2011. zabilježeno je ukupno 15 infekcija s V. inaequalis.

\section{Rezultati i rasprava}

Dvije istraživane godine 2011. i 2012. su sa meteorološkog gledišta bile potpuno različite godine. Tijekom 2011. godine bilo je više sušnih mjeseci tj. zabilježeno je ukupno 7 primarnih infekcija s krastavošću ploda i mrljavosti lista jabuke dok je u 2012. zabilježeno duplo više, tj. ukupno 15 primarnih infekcija. Promatrajući raspored oborina i pritisak bolesti po godinama ne čudi rezultat da su gotovo sve sorte iz standardnog sortimenta tijekom 2011. godine pokazale zadovoljavajuće rezultate u sustavu ekološke zaštite u odnosu na 2012. (Grafikon 2 i 4), što potvrđuju istraživanja američkih znanstvenika (Reganold i sur., 2001; Peck i sur, 2006).

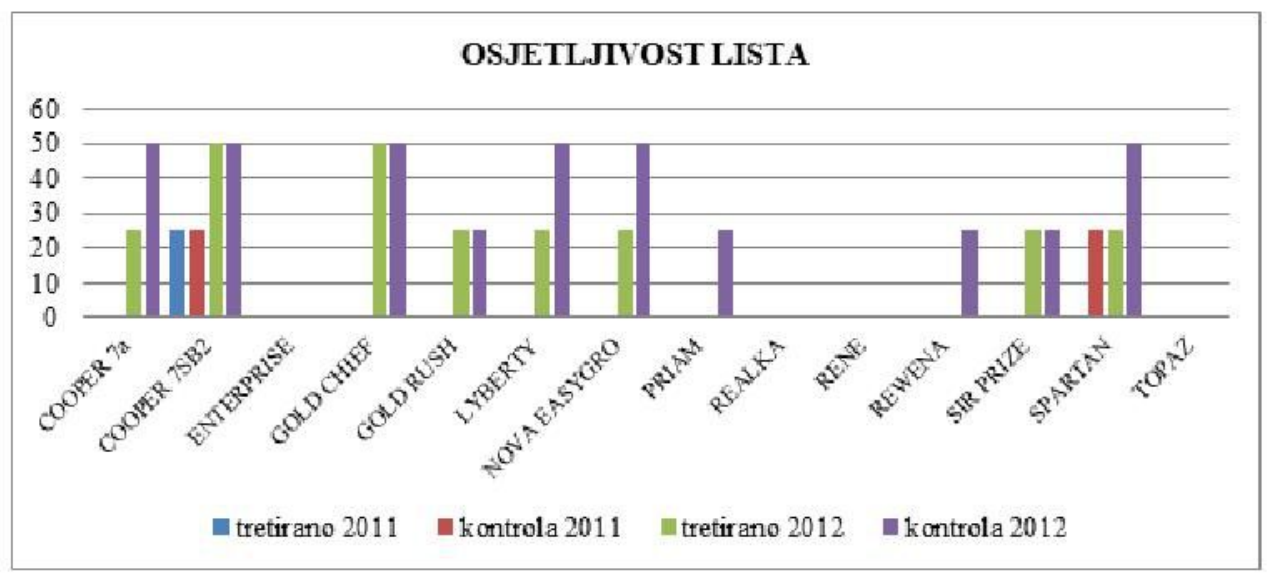

Grafikon 1. Ocjena osjetljivost lista tolerantnog sortimenta na krastavost ploda i mrljavost lista jabuke u ekološkom tretmanu i u kontroli (2011-2012); 0- bez simptoma; 25 - do 25\% lisne površine zaraženo; 50 - više od $25 \%$ lisne površine zaraženo

Figure 1. Evaluation of leaf sensitivity of tolerant varieties to apple scab in ecological treatment and in control (2011-2012); 0- without symptoms; 25 - up to $25 \%$ of leaf surface infected; 50 - over $25 \%$ of leaf surface infected.

Listovi sorte 'Priam' i sorte 'Rewena' u ekološkom tretmanu su bili potpuno zdravi tj. nisu imali simptome mrljavosti lista niti u jednoj istraživanoj godini osim tijekom 2012. (godina s nadprosječnom količinom oborina u vegetacijskom periodu), kad su se simptomi pojavili na netretiranom kontrolnom tretmanu. U vlažnijoj 2012. godini nije bila dovoljna genetska otpornost sorte na patogena već je dokazana zadovoljavajuća učinkovitost ekoloških preparata u suzbijanju glavne biljne bolesti na jabuci (Grafikon 1). Sorte 'Enterprise', 'Realka', 'Rene' i 'Topaz' su u ekološkom tretmanu kao i u kontrolnom tretmanu imale potpuno zdrave listove u obje istraživane godine. One su dokazale svoju potpunu genetsku otpornost na mrljavost lista kako u sušnoj tako i u vlažnoj godini. Nije zabilježena razlika između tretmana i kontrole (Grafikon 1). 


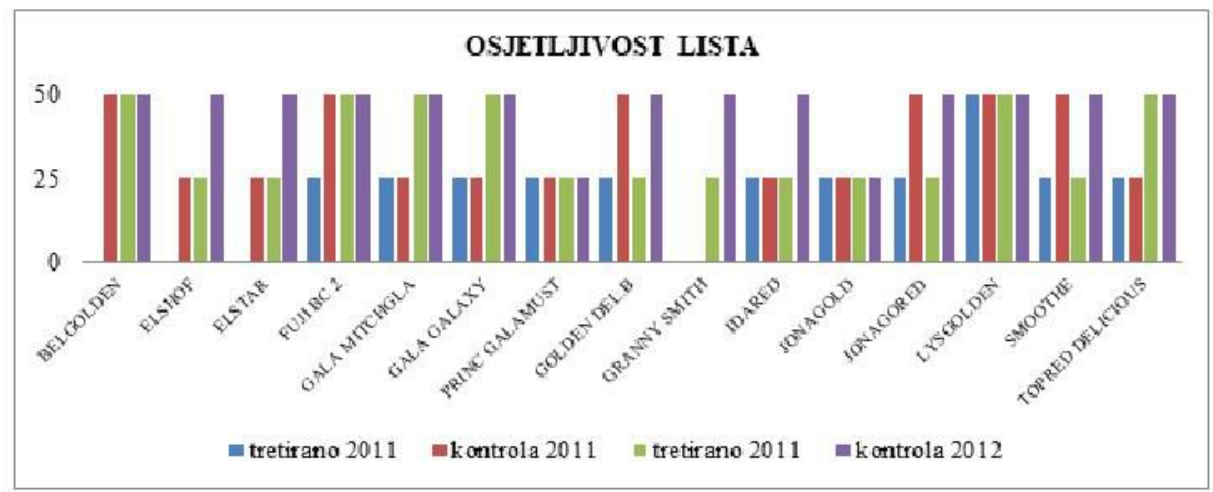

Grafikon 2. Ocjena osjetljivosti lista standardnog sortimenta na krastavost ploda i mrljavost lista jabuke u ekološkom tretmanu i u kontroli (2011-2012); 0- bez simptoma; 25 - do 25\% lisne površine zaraženo; 50 - više od $25 \%$ lisne površine zaraženo

Figure 2. Evaluation of leaf sensitivity of standard varieties to apple scab in ecological treatment and control (2011-2012); 0- without symptoms; 25 - up to $25 \%$ of leaf surface infected; 50 - over $25 \%$ of leaf surface infected.

Od standardnih sorti u istraživanju najotpornijim sortama u sušnoj godini, u ekološkom tretmanu i u kontroli su se pokazale sorte 'Elshof', 'Elstar' i 'Granny Smith', za razliku od vlažne 2012. godine u kojoj je do $25 \%$ lisne površine bilo zahvaćeno simptomima mrljavosti lista (Grafikon 2)

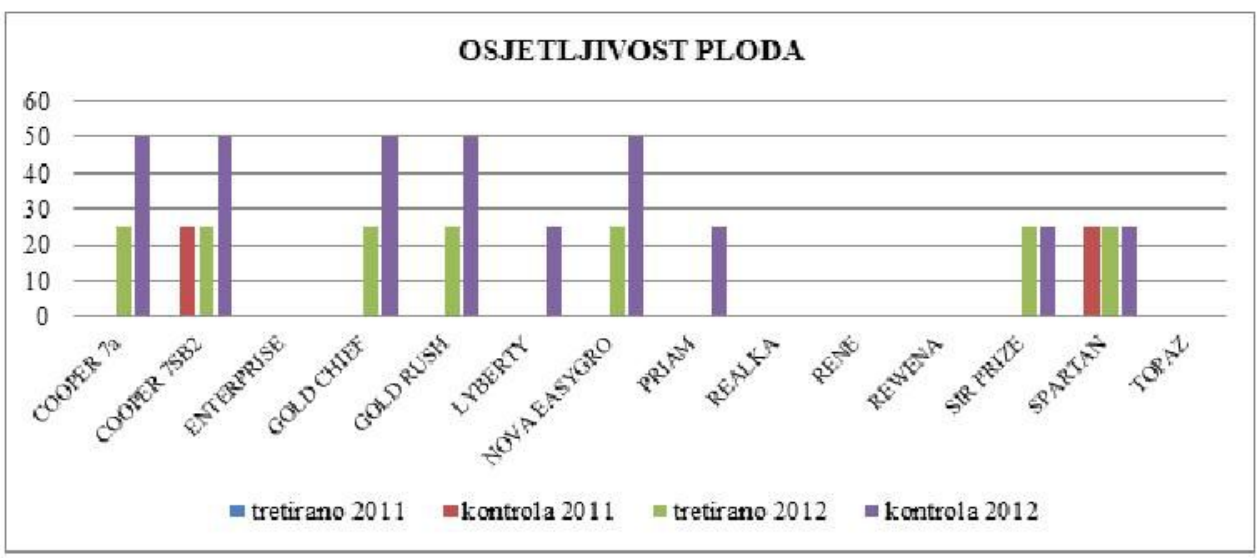

Grafikon 3. Ocjena osjetljivosti ploda tolerantnog sortimenta na krastavost ploda i mrljavost lista jabuke u ekološkom tretmanu i u kontroli (2011-2012); 0 - plod bez simptoma; 25 - do $1 \mathrm{~cm}^{2}$ površine simptoma na plodu; 50 - preko $1 \mathrm{~cm}^{2}$ površine simptoma na plodu

Graph 3. Evaluation of fruit sensitivity of tolerant apple varieties to apple scab in ecological treatment and in control (2011-2012); 0 - fruit without symptoms; 25 - up to $1 \mathrm{~cm}^{2}$ of symptoms present on the fruit; 50 - over $1 \mathrm{~cm}^{2}$ of symptoms present on the fruit

Analiza ploda sorti koje su deklarirane kao tolerantne na patogena Venturia inaequalis je pokazala da su sorte 'Enterprise', 'Realka', 'Rene', 'Rewena' i 'Topaz' u obje istraživane godine imale „čiste" plodove bez prisutnih simptoma bolesti (Grafikon 3). 


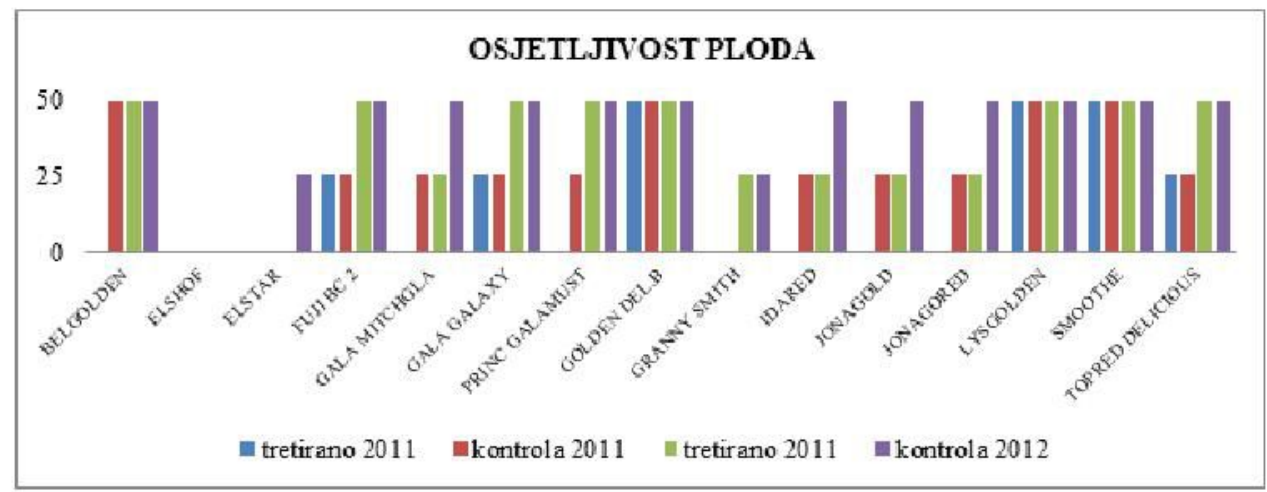

Grafikon 4. Ocjena osjetljivosti ploda standardnog sortimenta na krastavost ploda i mrljavost lista jabuke u ekološkom tretmanu i u kontroli (2011-2012); 0 - plod bez simptoma; 25 - do $1 \mathrm{~cm}^{2}$ površine simptoma na plodu; 50 - preko $1 \mathrm{~cm}^{2}$ površine simptoma na plodu

Graph 4. Evaluation of fruit sensitivity of standard apple varieties to apple scab in ecological treatment and control (2011-2012); 0 - fruit without symptoms; 25 - up to $1 \mathrm{~cm}^{2}$ of symptoms present on the fruit; 50 - over $1 \mathrm{~cm}^{2}$ of symptoms present on the fruit

$\mathrm{U}$ obje istraživane godine najbolje rezultate otpornosti ploda među standardnim sortama u ekološkom tretmanu pokazale su sorte 'Elshof' i 'Elstar'. Međutim, s obzirom na visinu priroda u ovom istraživanju te sorte nisu dale najviši prirod. Ukupan prirod svih sorti je bio puno veći u 2011. godini u odnosu na 2012. (Grafikon 5 i 6). Razlog su nepovoljne klimatske prilike u fenološkoj fazi cvatnje jabuke što je uvjetovalo lošiju oplodnju i niži prirod u 2012. godini (Grafikon 6).

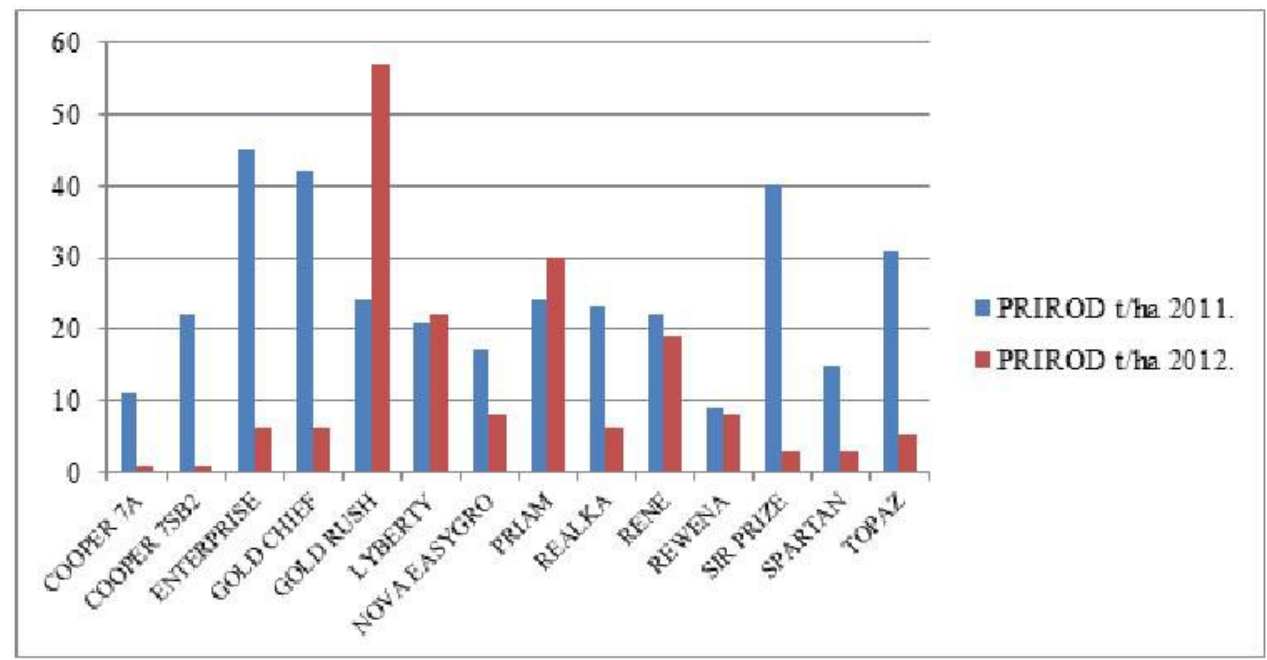

Grafikon 5. Prirod tolerantnih sorti (2011-2012) u ekološkom tretmanu Figure 5. The yield of tolerant varieties (2011-2012) in ecological treatment. Prirod tolerantnih sorti je bio veći u 2011. godini, osim kod sorata 'Gold Rush' i 'Priam' koja je imala u lošijoj godini (2012.) znatno veći prirod u odnosu na 2011. godinu (Grafikon 5). 


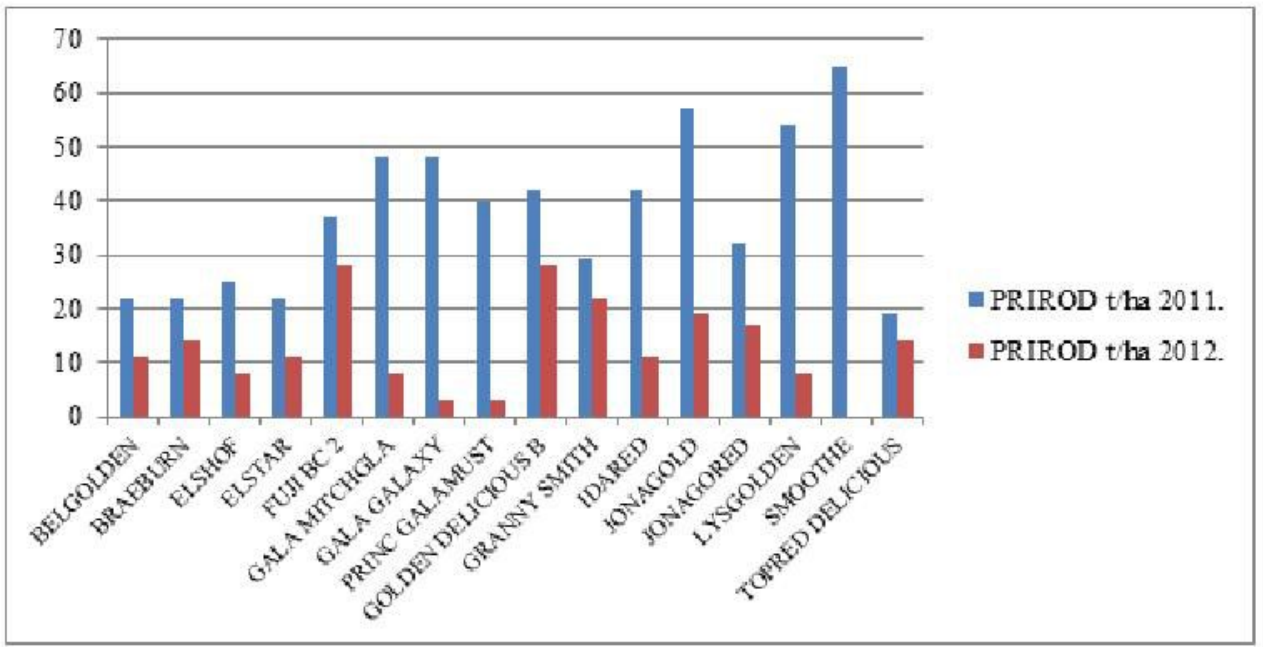

Grafikon 6. Prirod standardnih sorti (2011-2012) u ekološkom tretmanu

Figure 6. The yield of standard varieties (2011-2012) in ecological treatment

\section{Zaključak}

Tijekom dvogodišnjih istraživanja utvrđeno je da su sorte 'Enterprise', 'Rene', 'Rewena' i 'Topaz' otporne sorte na krastavost ploda i mrljavost lista. Sorta 'Priam' pokazala je svoju tolerantnost, ali i dobre rezultate uslijed ekološkog tretmana, što je rezultiralo zdravim listovima i plodovima i u vlažnoj 2012. godini u odnosu na kontrolu. Sorta 'Enterprise' je u povoljnoj proizvodnoj godini imala najveći prirod ( $45 \mathrm{t} / \mathrm{ha}$ ).

Od standardnog sortimenta u istraživanju, sorte 'Elshof', 'Elstar' i 'Granny Smith' su dale dobre rezultate u ekološkom tretmanu u 2011., sušnijoj godini u istraživanju te nisu imale simptoma krastavosti na plodovima. Sorte 'Elshof' i 'Elstar' i u vlažnoj 2012. godini nisu pokazale simptome zaraze na plodu u tretmanu u odnosu na kontrolu, već je bolest bila prisutna i ograničena samo na listovima.

\section{Literatura}

Andrews, P., Fellman, J., Glover, J., Reganold, J. (2001) Soil and plant mineral nutrition and fruit quality under organic, conventional and integrated apple production systems in Washington State, USA. Acta Horticulturae 564, $291-298$.

Anonymous (2002) Guidelines for integrated production of pome fruit 3rd Edition IOBC WPRS Bull. 25.

Biggs, A. (1990) Apple Scab, 6-9. In: Compendium of apple and pear diseases. American phytopathological society, St Paul Minnesota, 100.

Carroll J.E., Robinson T.L. (2004) The New York State apple IFP, our'most friendly practices'. New York Fruit Quarterly, 1258.

Chevalier, M., Lespinasse, Y., Renaudin, S. (1991) A microscopic study of tihe different classes of symptoms coded by tihe Vf gene in apple for resistance to scab (Venturia inaequalis). Plant Pathology 40, 249-256.

Gonda, I., Holb, I., Bitskey, K. (2000) Rate of scab infection and quality parameters of apple fruit in organic and integrated production systems. International Journal of Horticultural Science 6, 63-67.

Janse, J.( 1993) Breeding of resistant apple varieties in tihe Netherlands. Acta Horticulturae 347, $143-148$.

Kellerhals, M., Mouron, P., Goerre, M., Gessler, C. (1997) Breeding apples for disease resistance - an integrated approach towards sustainable and economic orchard ecosystems, Proceedings of tihe 4th workshop on Integrated control of pome fruit diseases, Croydon, 134-140.

Peck G.M., Andrews P.K., Reganold J.P., Fellman J.K. (2006) Apple orchard productivity and fruit quality under organic, conventional, and integrated management. HortScience, 41, 99-107.

Reganold J.P., Glover J.D., Andrews P.K., Hinman H.R. (2001) Sustainability of three apple production systems. Nature, 410, 926-930. 
Sandskär, B. ( 2003) Apple scab (Venturia inaequalis) and pests in organic orchards. Ph D dissertation, Agraria 378, SLU, Sweden. ISBN 91-576-6416-1.

Sansavini S., Donati F., Costa F., Tartarini, S. (2004) Advances in apple breeding for enhanced fruit quality and resistance to biotic stresses: new varieties for tihe European market. Journal of Fruit and Ornamental Plant Research, 12, 13-52.

Prispjelo/Received: 5.6.2019.

Prihvaćeno/Accepted:11.07.2019.

Original scientific paper

\title{
Possibilities of standard apple varieties in organic production
}

\begin{abstract}
During the last decade, we are witnessing climate change, occurring due to the various impacts harmful to the environment. In agricultural production, solutions are sought in organic production. The goal of organic production is to achieve high productivity and quality of the products by relying on the use of methods that do not interfere with natural equilibrium and do not have negative affect on agro-ecological system as well as human health. Considering the high cost of new planting when switching to organic production, the aim of this study was to determine the susceptibility of standard varieties to apple scab (Venturia inaequalis), the most important disease of apple, in organic pest control programme compared with control. Another goal was to determine the effectiveness of organic pest control programme on tolerant apple varieties compared to control. This research was conducted at the Agricultural Institute Osijek, Department for Fruit Growing and it lasted for two years (2011 - 2012). A total of 29 apple varieties were included in the study. Two-year research results showed that 'Elshof' and 'Elstar' varieties were the most resistant to the disease in organic treatment compared to control, but also compared to all the other standard varieties in the study. Among tolerant varieties, the best result was recorded for 'Enterprise'variety, while 'Priam' variety showed a good result within the organic pest control programme and maintained the stability of the yield in both investigated years.
\end{abstract}

Keywords; organic control, apple, variety, scab, Venturia inaequalis 